\title{
1,8-Bis(bromomethyl)naphthalene in the synthesis of 1,5-diazacyclodecane and benz[de]isoquinoline proton sponges
}

\author{
Valery A. Ozeryanskii, Polina A. Vakhromova, and Alexander F. Pozharskii* \\ Department of Organic Chemistry, Southern Federal University \\ Zorge 7, 344090 Rostov-on-Don, Russian Federation \\ E-mail:apozharskii@sfedu.ru
}

\begin{abstract}
Dedicated to Professor Rosa M. Claramunt on the occasion of her 65th anniversary, and to recognise her outstanding contributions to heterocyclic and physical organic chemistry
\end{abstract}

DOI: $\underline{\text { http://dx.doi.org/10.3998/ark.5550190.p008.253 }}$

\begin{abstract}
A new 1,5-diazacyclodecane-based proton sponge 9 has been prepared by treatment of 1,8di(methylamino)naphthalene (7) with 1,8-bis(bromomethyl)naphthalene (8). Though the compound 9 is structurally related both to kinetically low-active 1,8bis(dimethylamino)naphthalene $(\mathbf{1}$, parent proton sponge) and kinetically active 1,8 bis(dimethylaminomethyl)naphthalene (2), X-ray and basicity studies have revealed that the proton sponge behavior of the former dominates. It is found that double alkylation of 1dimethylamino-8-methylaminonaphthalene (11) with $\mathbf{8}$ touches only the NHMe functionality and leads to the substitution of the $\mathrm{N}-\mathrm{Me}$ group, yielding the previously unknown benz $[d e]$ isoquinoline proton sponge 15. The reaction of 8 with 1,8-diaminonaphthalene or 2,2dimethyl-2,3-dihydroperimidine gives, along with other products, proton sponge 18 with two benzisoquinoline fragments.
\end{abstract}

Keywords: 1,8-Diaminonaphthalenes, 1,8-bis(bromomethyl)naphthalene, 1,5-diazacyclodecane, benz[de]isoquinoline, proton sponge, basicity

\section{Introduction}

It is generally known that an organic base to be assigned to the so-called "proton sponges", as for example 1,8-bis(dimethylamino)naphthalene (1, $\mathrm{p} K_{\mathrm{a}}=12.1$ in $\mathrm{H}_{2} \mathrm{O} ; 18.6$ in $\mathrm{MeCN}$ ), apart from high basicity, should possess a considerably reduced rate of proton addition-elimination (low kinetic activity). ${ }^{1,2}$ When the latter criterion is not satisfied it is more appropriate to use a term 'proton sponge-like' compound., A typical example is 1,8-bis(dimethylaminomethyl)- 
naphthalene 2, which is kinetically active despite the fact that its basicity $\left(\mathrm{p} K_{\mathrm{a}}=18.3\right.$ in $\left.\mathrm{MeCN}\right)$ closely resembles that of $\mathbf{1} .^{5}$<smiles>CN(C)c1cccc2cccc(N(C)C)c12</smiles>

1<smiles>CN(C)Cc1cccc2cccc(CN(C)C)c12</smiles>

2<smiles>CN(C)Cc1ccc(N(C)C)c2c(N(C)C)ccc(N)c12</smiles>

Some time ago one of us with co-workers tried to prepare naphthalene derivative $\mathbf{3}$, which can be considered as an interesting combination of bases $\mathbf{1}$ and $2 .{ }^{6}$ With this aim, the diamine $\mathbf{1}$ was treated with two equivalents of Eschenmoser's salt ( $N, N$-dimethylmethyleniminium chloride), but instead of $\mathbf{3}$ the 2-azoniaphenalene chloride $\mathbf{4}$ was isolated as the main product along with some of the mono-Mannich base 5 (Scheme 1). Notably, salt 4 is also formed by reaction of $\mathbf{5}$ with the Eschenmoser's reagent. It was assumed that equilibrium amounts of the hydrochloride of an initially-formed bis-Mannich base $3 \mathbf{H}^{+} \mathrm{Cl}^{-}$immediately loses a dimethylamine molecule to generate the resonance-stabilized naphthylmethyl cation $\mathbf{6}$ which then cyclizes to 4 .

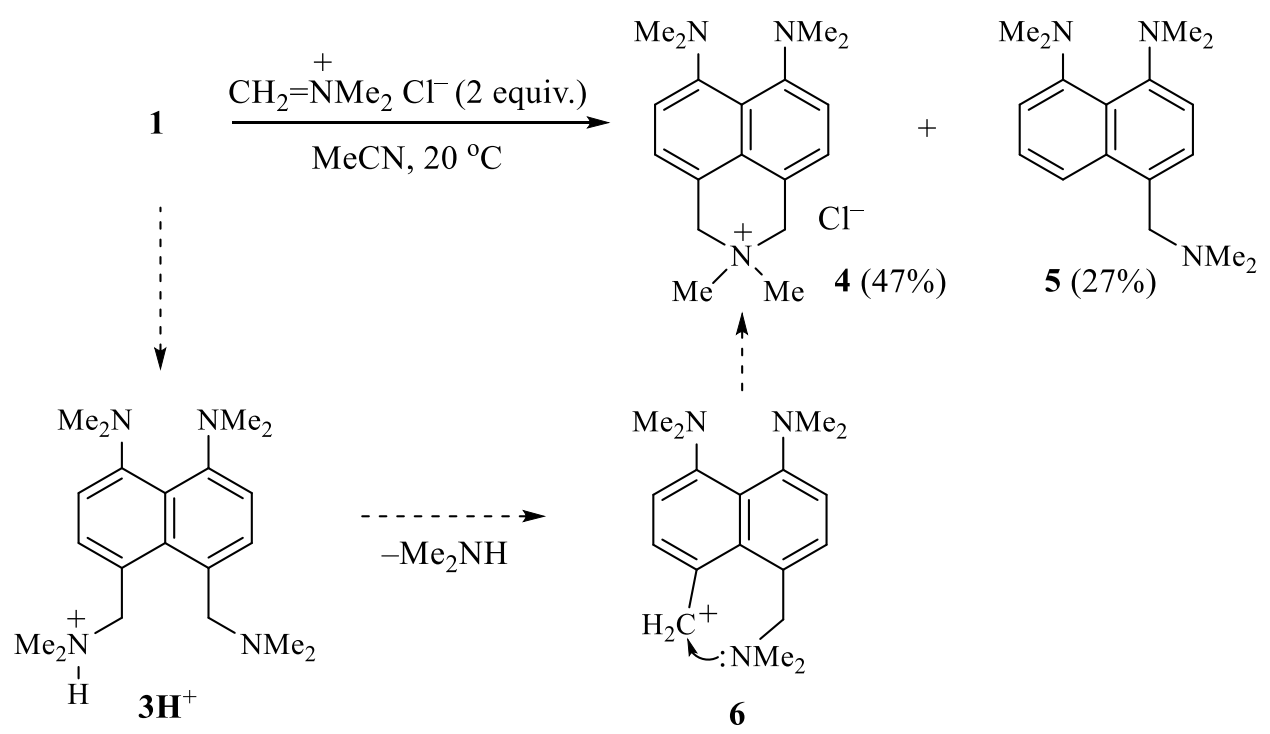

Scheme 1. Attempted bis-aminomethylation of compound 1.

\section{Results and Discussion}

In the present work we have tried to follow up the same idea approaching it from the other side. For this, we have prepared and studied diazacyclodecane 9 in which two methylamino groups 
simultaneously belong to 1,8-di(aminomethyl)- and 1,8-diaminonaphthalene fragments. This macrocycle was synthesized in $92 \%$ yield by alkylation of 1,8-di(methylamino)naphthalene (7) with 1,8-bis(bromomethyl)naphthalene (8) in the presence of triethylamine (Equation 1).

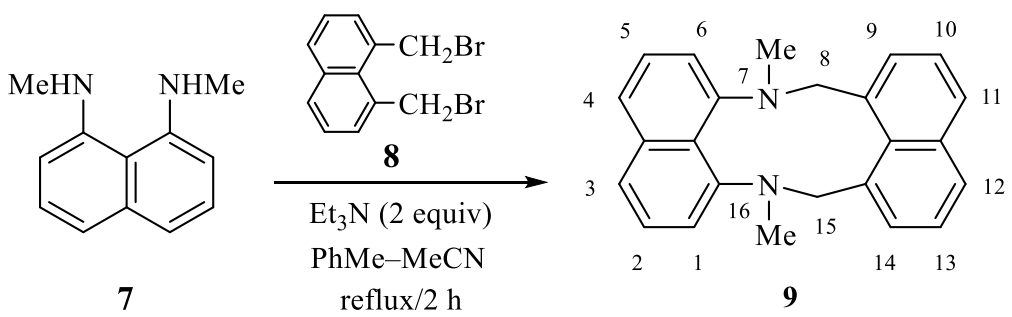

Equation 1. Synthesis of diazacyclodecane derivative 9.

Compound 9 forms yellowish crystals with mp 204-206 ${ }^{\circ} \mathrm{C}$ (from $\mathrm{MeCN}$ ) readily dissolving in $\mathrm{CH}_{2} \mathrm{Cl}_{2}, \mathrm{CHCl}_{3}$ and EtOAc. As it is depicted in Figure 1, molecule 9 is twisted along the $\mathrm{N}-$ $\mathrm{CH}_{2}$ links in such a way that both naphthalene planes are settled at a $70^{\circ}$ angle to each other. 1,8 Di(methylene)naphthalene moiety "crosses" the internitrogen space and the $N$-methyl groups occupy trans-positions relative to the diaminonaphthalene residue (Figure 1b).

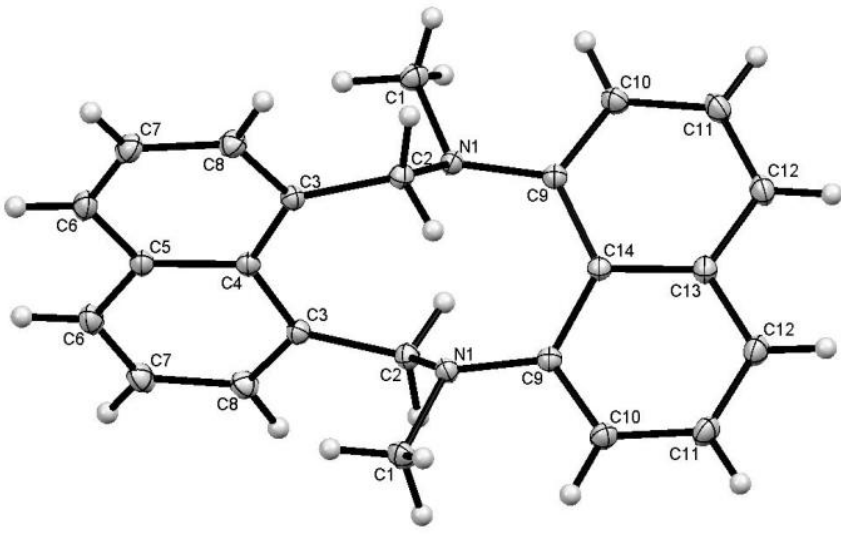

a)

Figure 1. Molecular structure of diazacyclodecane 9. (a) General view. (b) View from the side of the 1,8-di(methylene)naphthalene moiety (100 K).

In the ${ }^{1} \mathrm{H}$ NMR spectrum of 9 in $\mathrm{CDCl}_{3}$, the $\mathrm{N}-\mathrm{CH}_{3}$ groups, due to the shielding caused by the paramagnetic component of the additional naphthalene system, resonate at $\delta 2.55 \mathrm{ppm}$ against 2.7-2.9 ppm for ordinary proton sponges. ${ }^{2}$ As expected, geminal $\mathrm{N}-\mathrm{CH}_{2}-\mathrm{Ar}$ protons are non-equivalent and give two doublets at 3.87 and $6.23 \mathrm{ppm}$ with $J_{\text {gem }}=14.5 \mathrm{~Hz}$. Variable temperature experiments showed that in $\mathrm{CDCl}_{3}$ the spectrum remains unchanged up to $55{ }^{\circ} \mathrm{C}$; the dynamics in the diastereotopic $\mathrm{N}-\mathrm{CH}_{2}-\mathrm{Ar}$ fragments can be registered at considerably higher temperatures. Thus, in DMSO- $\mathrm{d}_{6}$ the doublet pattern of two $\mathrm{CH}_{2}$ signals is smoothed at $80{ }^{\circ} \mathrm{C}$ 
and coalesced at $140{ }^{\circ} \mathrm{C}$ to give one distinct peak at $175^{\circ} \mathrm{C}$ (Figure 2). The estimated free energy of activation for the conformational processes giving rise to these spectral changes is $\Delta G^{\neq}$ $18.6 \pm 0.2 \mathrm{kcal} / \mathrm{mol}$. This is considerably higher than that for binaphthyl derivative $\mathbf{1 0}$, in which the methylene proton averaging occurs already at $70{ }^{\circ} \mathrm{C} .{ }^{7}$

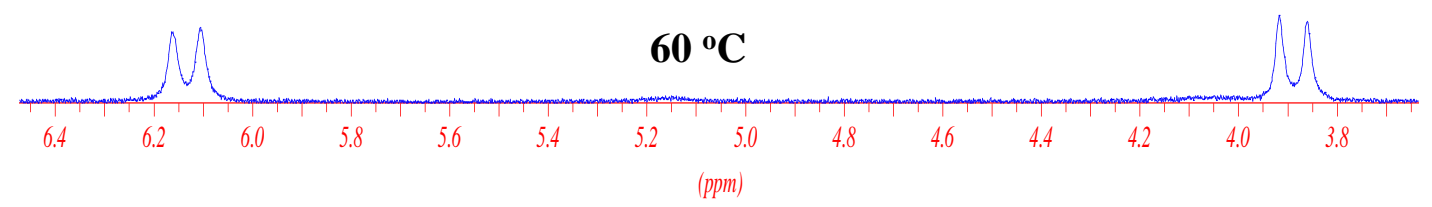

$80{ }^{\circ} \mathrm{C}$

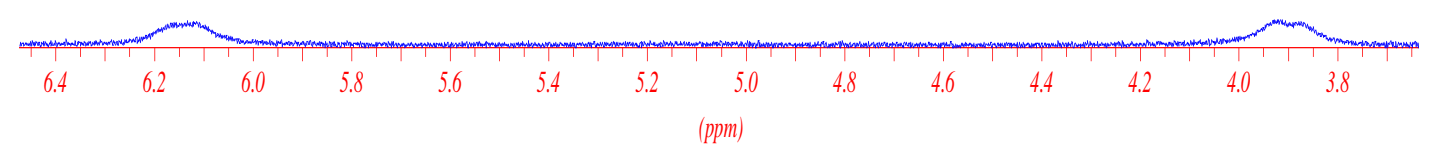

$140{ }^{\circ} \mathrm{C}$

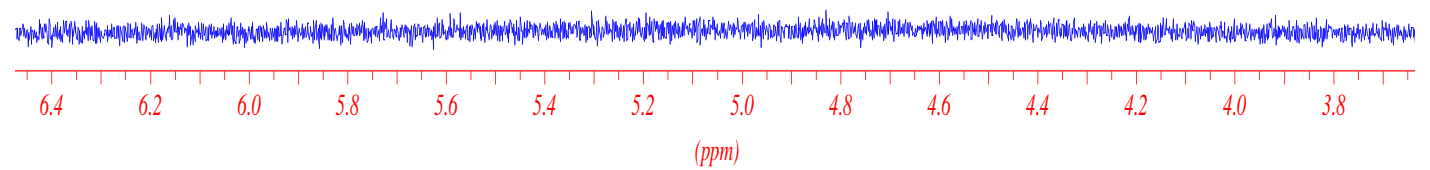

\section{$175^{\circ} \mathrm{C}$}

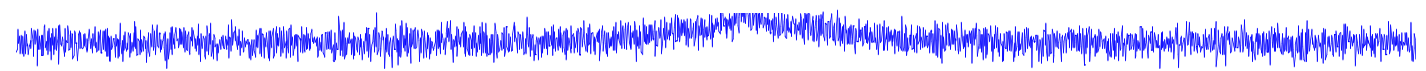

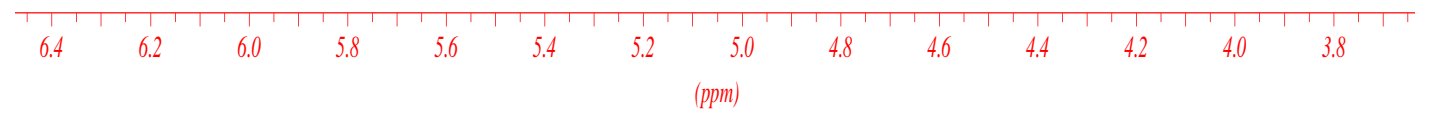

Figure 2. ${ }^{1} \mathrm{H}$ NMR patterns of the $\mathrm{N}-\mathrm{CH}_{2}-\mathrm{Ar}$ region of diazacyclodecane 9 as a function of temperature $\left(250 \mathrm{MHz}, \mathrm{DMSO}-\mathrm{d}_{6}\right)$.<smiles>CN1Cc2ccc3ccccc3c2-c2c(ccc3ccccc23)C1</smiles>

10 
Treatment of an ethyl acetate solution of 9 with one equivalent of $\mathrm{HClO}_{4}$ followed by addition of diethyl ether leads to precipitation of the symmetric mono-perchlorate $9 \mathbf{H}^{+} \mathrm{ClO}_{4}^{-}$in $95 \%$ yield (Equation 2 ).

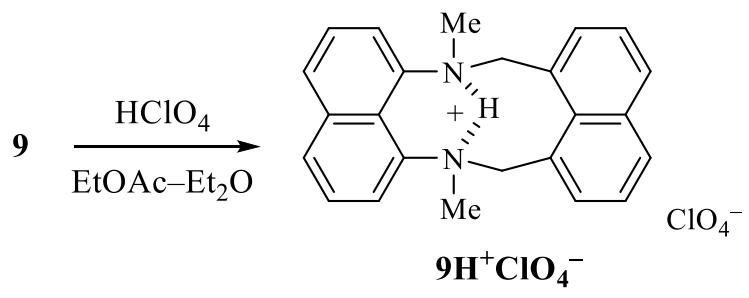

Equation 2. Synthesis of monoprotonated diazacyclodecane $9 \mathbf{H}^{+} \mathrm{ClO}_{4}^{-}$.

X-Ray measurements of this salt demonstrated that two chelate rings, six- and eightmembered, are present simultaneously in the cation, and the symmetry plane goes through both naphthalene C9-C10 bonds (chemical numbering) (Figure 3). Interestingly, that the coordination with a proton changes the molecular conformation from trans-in the parent base 9 to $\mathrm{cis}$ - in its salt $9 \mathrm{H}^{+} \mathrm{ClO}_{4}^{-}$. As a result, both naphthalene systems become nearly coplanar and the $\mathrm{N}-\mathrm{Me}$ groups now arrange at one side of the middle molecular plane. Regrettably, the local pseudoplane of symmetry and strong cation and anion disordering and twinning in the crystal do not allow determining exact parameters of the intramolecular hydrogen bond. Nevertheless, one can affirm that the N...N distance on protonation decreases by 7-8\% (from 2.917 to $2.68-2.72 \AA$ ). In the ${ }^{1} \mathrm{H}$ NMR spectra of salt $\mathbf{9} \mathbf{H}^{+} \mathrm{ClO}_{4}{ }^{-}$, the encircled proton ${ }^{8}$ is very deshielded, resonating at $\delta$ $19.55 \mathrm{ppm}$ in DMSO- $\mathrm{d}_{6}$ and at $19.95 \mathrm{ppm}$ in $\mathrm{CD}_{3} \mathrm{CN}$. Such behavior is typical for cations of many proton sponges. ${ }^{2}$

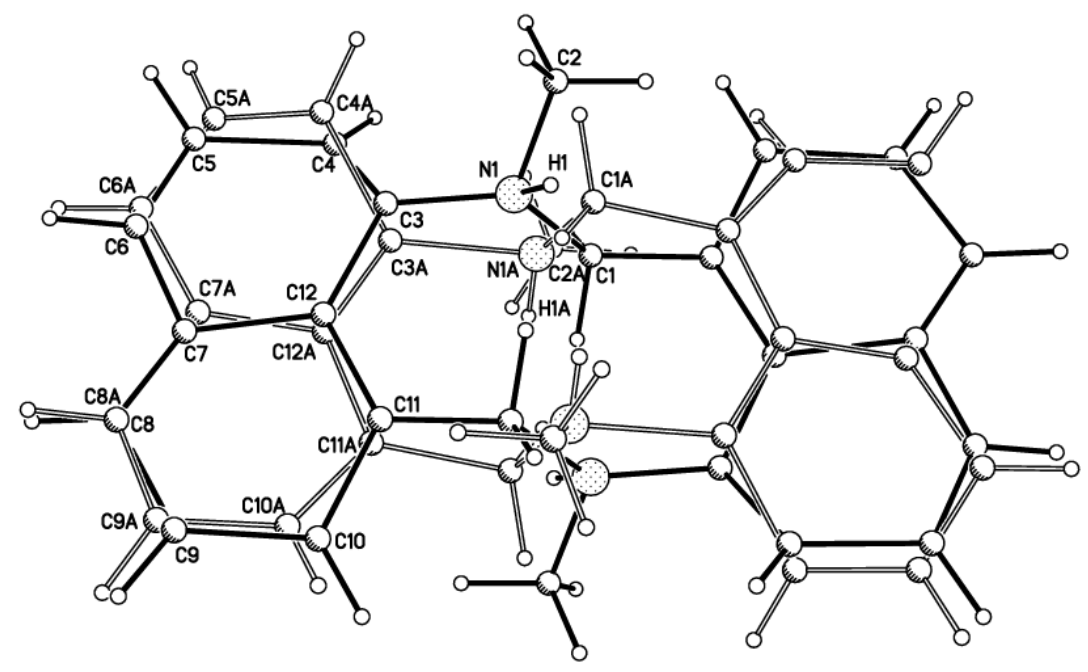

Figure 3. General view of perchlorate $9 \mathrm{H}^{+} \mathrm{ClO}_{4}^{-}$(the cation and the internal proton are disordered and the anion is omitted for clarity, the $\mathrm{N}$ atoms and the $\mathrm{C}$ atoms of the $\mathrm{CH}_{2}$ links may be arbitrarily interchanged, $100 \mathrm{~K}$ ). 
Since diamine 2 , in accordance with literature data, ${ }^{5}$ is kinetically active and, unlike the proton sponge 1, easily forms a dication, it was interesting to study the possibility of double protonation of base 9. Our experiments, however, show that salt $\mathbf{9} \mathbf{H}^{+} \mathrm{ClO}_{4}{ }^{-}$does not undergo second protonation in low basic $\mathrm{CD}_{3} \mathrm{CN}$ (more than 20 equivs of $\mathrm{HClO}_{4}$ were used). Thus, in this regard compound 9 is much closer to "proton sponge" $\mathbf{1}$ rather than to Mannich base 2 . The ${ }^{1} \mathrm{H}$ NMR monitoring of the transprotonation process between salt $9 \mathbf{H}^{+} \mathrm{ClO}_{4}{ }^{-}$and neutral base $\mathbf{1}$ in DMSO-d $_{6}$ gave for $9 \mathrm{p} K_{\mathrm{a}}=6.7\left(\mathbf{1}\right.$ in DMSO has $\mathrm{p} K_{\mathrm{a}}=7.5$, see ref. 9 ). The six-fold weaker basicity of 9 in comparison with 1 can be ascribed to the $-I$-effect of the second naphthalene ring.

Next, we discovered unexpectedly that the interaction of $\mathbf{8}$ with 1-dimethylamino-8(methylamino)naphthalene (11) is accompanied by demethylation of the NHMe group, leading in $53 \%$ yield to compound $\mathbf{1 5}$, which is isomeric with $\mathbf{9}$ (Scheme 2). The reaction seems to proceed in three successive $S_{N}$ processes involving intermediates 12-14 and is reminiscent of the proton sponge realkylation reported by us earlier. ${ }^{10}$ Undoubtedly, a key stage here is the nucleophilic attack of bromide onto the Me group in 12, which is facilitated by acidic catalysis through the formation of hydrogen bond, while the overall process is regulated by entropy factors favoring cyclization to the six-membered ring rather than the ten-membered as it would be in 9.

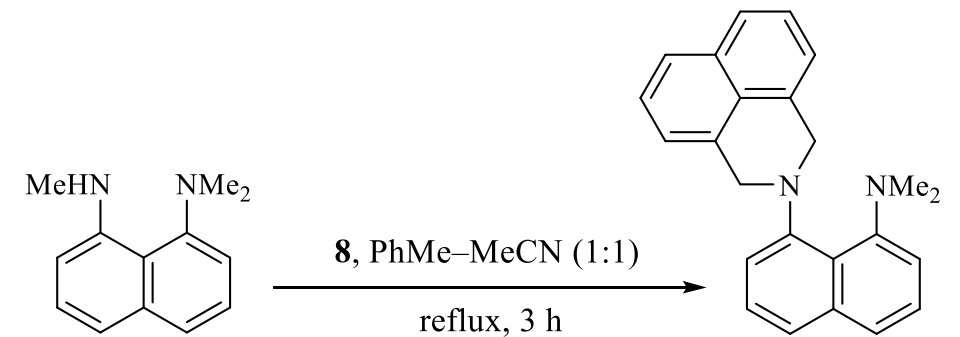

11

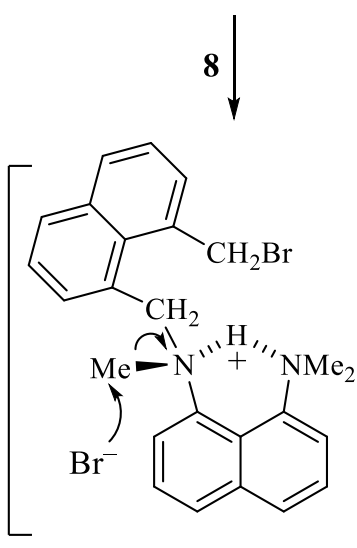

12

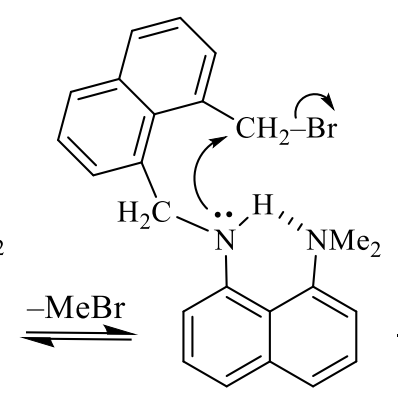

13
15<smiles>C[BiH](C)Br</smiles>

Scheme 2. Synthesis of benz[de]isoquinoline derivative $\mathbf{1 5}$. 
As seen from Scheme 2, the auxiliary base $\mathrm{Et}_{3} \mathrm{~N}$ is not involved in the key steps and is not necessary for the reaction to perform. In fact, it can really lower the yield of $\mathbf{1 5}$ by premature abstraction of $\mathrm{HBr}$ from intermediate 12. Indeed, the interaction of diamine $\mathbf{1 1}$ with dibromide $\mathbf{8}$ in the presence of $\mathrm{Et}_{3} \mathrm{~N}$ lowers the yield of benzisoquinoline $\mathbf{1 5}$ and requires at least $5 \mathrm{~h}$ for consumption of $\mathbf{1 1 .}$

Unlike 9, methylene $\mathrm{N}-\mathrm{CH}_{2}-$ Ar protons in the ${ }^{1} \mathrm{H}$ NMR spectrum of $\mathbf{1 5}$ appear much closer in chemical shifts to give two doublets at 4.48 and $4.77 \mathrm{ppm}$ with $J_{\text {gem }}=14.5 \mathrm{~Hz}$ (ABq pattern). In the gas phase, the molecular ion of $\mathbf{1 5}$ is more stable than that of $\mathbf{9}$ (relative intensities are $80 \%$ and $52 \%$ at $70 \mathrm{eV}$, respectively), although both undergo the same mode of fragmentation giving rise to the main $[\mathrm{M}-185]^{+}$and $[\mathrm{M}-169]^{+}$peaks to form protonated acenaphthylene 16 with $\mathrm{m} / \mathrm{z} 153$ and $N$-methylated benzindole 17 with $\mathrm{m} / \mathrm{z}, 169$. The processes associated with the loss of $\mathrm{Me}$ or $\mathrm{NMe}_{2}$ fragments, which are typical for diamine $\mathbf{1}$ and its ring-functionalized derivatives, ${ }^{2}$ are observed only to a minor extent.

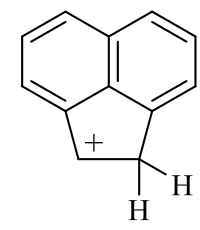

16

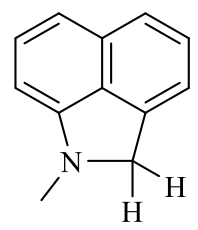

17

As expected, the reaction of dibromide 8 with unsubstituted 1,8-diaminonaphthalene gave bis(benzisoquinoline) sponge 18 (94\% yield) rather than the structural isomer 19. This comes from inspection of the methylene protons region in its ${ }^{1} \mathrm{H}$ NMR spectrum, which similarly to 15 contains the $\mathrm{ABq}$ spectral pattern centered at $4.40 \mathrm{ppm}$. The $\mathrm{p} K_{\mathrm{a}}$ values of compounds $\mathbf{1 5}$ and $\mathbf{1 8}$ in DMSO-d $\mathrm{d}_{6}$ measured by the competitive method (see above) turned out to be 5.6 and 4.7, respectively, displaying a further drop in basicity brought about by the benzisoquinoline fragments. The chemical shifts of the chelated NH-protons in the monoperchlorates of $\mathbf{1 5}$ and $\mathbf{1 8}$ in DMSO-d 6 were at $\delta 18.46$ and 19.33 ppm, respectively.

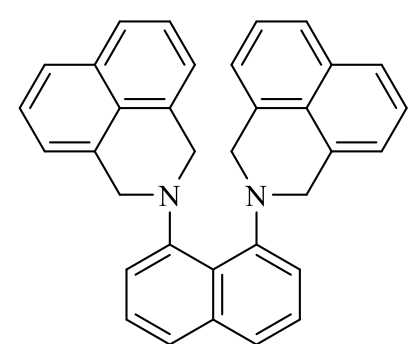

18

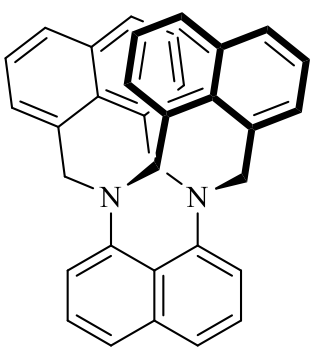

19

The intriguing topology of tri(naphthalene) molecule 19 might be achieved in the sequence described by Scheme 3. Hence, we also attempted synthesis of $\mathbf{1 9}$ using preliminary protection of the nitrogen atoms in 1,8-diaminonaphthalene $\mathbf{2 0}$ with the help of an internitrogen bridge, which 
could be deleted at the final step. Alkylation of $\mathbf{2 0}$ to $\mathbf{2 1}$, followed by deprotection to $\mathbf{2 2}$ and second alkylation should bring to $\mathbf{1 9}$. In the present work, $\mathrm{Z}=\mathrm{CMe}_{2}$ was tested, for which deprotection in acidic conditions is known. ${ }^{11}$

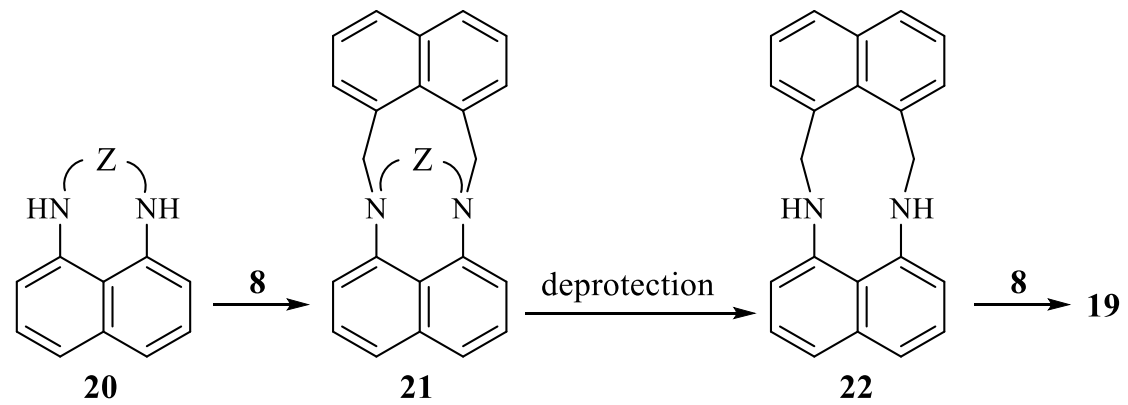

Scheme 3. Proposed synthesis of bicyclic derivative 19.

We have found that the isopropylidene bridge in 2,2-dimethyl-2,3-dihydroperimidine (23) is too labile (and perhaps bulky) to give species of type $\mathbf{2 1}$. The interaction of $\mathbf{2 3}$ with dibromide $\mathbf{8}$ resulted in a complex mixture, from which the three main compounds, namely $\mathbf{2 7}, \mathbf{2 8}$, and $\mathbf{1 8}$, could be isolated by chromatography (Scheme 4). Of them, benzisoquinolino[2,1-a]perimidine $\mathbf{2 7}$ prevailed with almost $30 \%$ yield, while diamines $\mathbf{1 8}$ and $\mathbf{2 8}$ were collected in lower yields. The key steps leading to these rather unusual products are shown in Scheme 4 and were previously observed at interaction of $\mathbf{2 3}$ with 1,2-bis(bromomethyl)benzene providing shorter alkylidene bridge. ${ }^{12}$ As seen, all products obtained are originated from spirocyclic intermediate 24, whose successive transformations via iminium salts 25 and $\mathbf{2 6}$ lead to a partial (for 27) or complete (for $\mathbf{2 8}$ and 18) loss of the bridge. Structure of bicyclic perimidine 27 is consistent with the mass, ${ }^{13} \mathrm{C}$ and ${ }^{1} \mathrm{H}$ NMR spectral data. Of particular interest are the prochiral $\mathrm{Ar}-\mathrm{CH}_{2}-\mathrm{N}$ methylene protons and the methyl $\mathrm{H}$ and $\mathrm{C}$ atoms of the isopropyl substituent. 


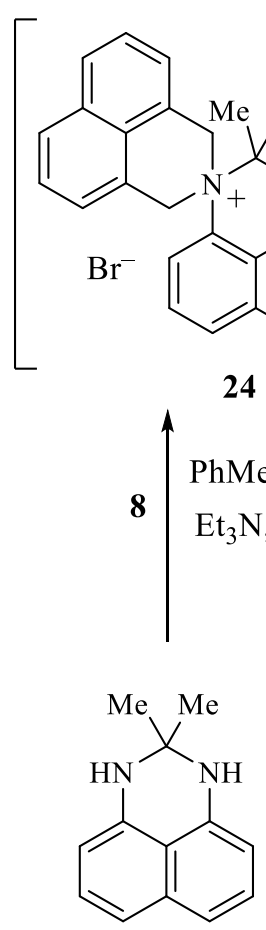

23<smiles>CC(C)=[NH+]c1cccc2cccc(N3Cc4cccc5cccc(c45)C3)c12</smiles>

25 hydrolysis<smiles>CC(C)Nc1cccc2cccc(N3C=NCc4cccc5cccc3c45)c12</smiles>

26<smiles>CC(C)N1c2cccc3cccc(c23)N2Cc3cccc4cccc(c34)C21</smiles>

$27,27 \%$

Scheme 4. Alkylation of dihydroperimidine 23 by 1,8-bis(bromomethyl)naphthalene.

Finally, it is noteworthy, that compounds 9, 15 and $\mathbf{1 8}$ represent rather stable analogues of the $N$-benzylated proton sponges and we did not notice any signs of their decomposition in acidic media. Previously, English investigators failed to measure the basicity of simple representatives of such compounds due to their easy debenzylation on treatment with acids. ${ }^{13,14}$

\section{Experimental Section}

General. ${ }^{1} \mathrm{H}$ and ${ }^{13} \mathrm{C}$ NMR spectra were recorded on a Bruker DPX-250 (250 MHz) spectrometer with the solvent residual peaks as the internal standard ( $\left.\delta / \mathrm{ppm},{ }^{\mathrm{n}} \mathrm{J} / \mathrm{Hz}\right)$. IR spectra were measured in Nujol on a FT FSM-1202 spectrometer. Mass spectra were obtained from a Finnigan MAT INCOS 50 instrument (electron impact, $70 \mathrm{eV}$ ). X-Ray measurements were conducted with a Bruker APEX II diffractometer (Mo-K $\mathrm{K}_{\alpha}$ line, graphite monochromator, $\omega$ scanning). The structures were solved by direct methods and refined by the full-matrix leastsquares against $F^{2}$ in anisotropic (for non-hydrogen atoms) approximation. All hydrogen atoms were placed in geometrically calculated positions and were refined in isotropic approximation in riding model with the $U_{\text {iso }}(\mathrm{H})$ parameters equal to $\mathrm{n} \cdot U_{\text {eq }}\left(\mathrm{C}_{\mathrm{i}}\right)\left(\mathrm{n}=1.2\right.$ for $\mathrm{CH}$ and $\mathrm{CH}_{2}$ groups and $\mathrm{n}=1.5$ for $\mathrm{CH}_{3}$ groups), where $U\left(\mathrm{C}_{\mathrm{i}}\right)$ are respectively the equivalent thermal parameters of the atoms to which the corresponding $\mathrm{H}$ atoms are bonded. The $\mathrm{H}(\mathrm{N})$ hydrogen atoms were found in 
difference Fourier synthesis and refined in isotropic approximation. CCDC 942559 (for 9) and 942560 (for $\mathbf{9 H}^{+} \mathrm{ClO}_{4}^{-}$) contain the supplementary crystallographic data for this paper. These data can be obtained free of charge from the Cambridge Crystallographic Data Centre via www.ccdc.cam.ac.uk/data_request/cif. Thin layer chromatography was carried out on $\mathrm{Al}_{2} \mathrm{O}_{3}$ and on silica gel (70-230 mesh, Aldrich). The progress of reactions and the purity of products were monitored by TLC on $\mathrm{Al}_{2} \mathrm{O}_{3}$ and Silufol plates; development with iodine and bromine vapor. The melting points were measured in sealed capillaries. The solvents were purified and dried by standard methods. Elemental analyses were carried out on a PerkinElmer 2400 analyzer.

Proton complexes with perchloric acid (hydroperchlorates) were prepared by mixing equimolar amounts of bases $\mathbf{9}, \mathbf{1 5}$, or 18 (usually $0.1 \mathrm{mmol}$ ) and $60 \%$ aqueous $\mathrm{HClO}_{4}$ in a minimum volume of EtOAc ( 2 to $5 \mathrm{~mL}$ ) followed by 5 -fold dilution with $\mathrm{Et}_{2} \mathrm{O}$. The residue thus formed was washed with $\mathrm{Et}_{2} \mathrm{O}$, vacuum dried and recrystallized from $\mathrm{MeCN}$ to give the desired salts almost quantitatively.

7,16-Dimethyl-7,8,15,16-tetrahydrodinaphtho[1,8-bc:1',8' -gh][1,5]diazecine $\quad(9) . \quad 1,8$ Di(methylamino)naphthalene ${ }^{11}(0.2 \mathrm{~g}, 1.1 \mathrm{mmol}), 1,8$-bis(bromomethyl)naphthalene ${ }^{15}(0.35 \mathrm{~g}$, $1.1 \mathrm{mmol})$ and triethylamine $(0.3 \mathrm{~mL}, 2.2 \mathrm{mmol})$ in a mixture of toluene $(3 \mathrm{~mL})$ and acetonitrile $(3 \mathrm{~mL})$ was refluxed for two hours. The reaction mixture was poured into ice water $(30 \mathrm{~mL})$ and basified with a potassium hydroxide to $\mathrm{pH} 10-11$. The product was extracted with dichloromethane $(3 \times 15 \mathrm{~mL})$, the organic phase was dried over $\mathrm{Na}_{2} \mathrm{SO}_{4}$, the solvent was evaporated and the residue was purified by column chromatography $\left(\mathrm{Al}_{2} \mathrm{O}_{3}\right.$, chloroform) to afford $\mathbf{1}(0.34 \mathrm{~g}$, $92 \%$ ) as yellowish crystals; mp 204-206 ${ }^{\circ} \mathrm{C}(\mathrm{MeCN}) .{ }^{1} \mathrm{H} \mathrm{NMR}\left(\mathrm{CDCl}_{3}\right): \delta=2.55(\mathrm{~s}, 6 \mathrm{H}, \mathrm{NMe})$, $3.87\left(\mathrm{~d},{ }^{2} J 14.5 \mathrm{~Hz}, 2 \mathrm{H}, 8-\mathrm{H}, 15-\mathrm{H}\right), 6.24$ (d, $\left.{ }^{2} J 14.5 \mathrm{~Hz}, 2 \mathrm{H}, 8-\mathrm{H}, 15-\mathrm{H}\right), 6.99$ (dd, ${ }^{3} J$ 7.6, ${ }^{4} J 1.0$ Hz, 2 H, 1-H, 6-H), 7.33-7.48 (m, 8 H, 2-H, 3-H, 4-H, 5-H, 9-H, 10-H, 13-H, 14-H), 7.83 (dd, ${ }^{3} J$ $\left.7.3,{ }^{4} J 1.6 \mathrm{~Hz}, 2 \mathrm{H}, 11-\mathrm{H}, 12-\mathrm{H}\right) .{ }^{13} \mathrm{C} \mathrm{NMR}\left(\mathrm{CDCl}_{3}\right): \delta=39.0(\mathrm{~N}-\mathrm{Me}), 68.3\left(\mathrm{~N}-\mathrm{CH}_{2}-\mathrm{Ar}\right), 114.3$, $122.7,123.3,125.3,126.2,130.2,130.4,132.2,137.2,137.9,138.6,149.0 . \mathrm{MS}, \mathrm{m} / \mathrm{z}(\%): 338$ $[\mathrm{M}]^{+}(52), 323$ (14), 292 (11), 197 (47), 186 (86), 169 (37), 153 (100), 127 (14), 115 (11). $\mathrm{C}_{24} \mathrm{H}_{22} \mathrm{~N}_{2}$ (338.45): calcd. C 85.17, H 6.55, N 8.28; found C 85.32, H 6.12, N 8.07\%. 7,16Dimethyl-7,8,15,16-tetrahydrodinaphtho[1,8-bc:1',8'-gh][1,5]diazecine hydroperchlorate (9· HClO $\left._{4}\right)$ : grey to colorless crystals, mp 278-279 ${ }^{\circ} \mathrm{C}(\mathrm{MeCN}) .{ }^{1} \mathrm{H}$ NMR $\left(\mathrm{DMSO}-\mathrm{d}_{6}\right): \delta=2.95$ (d, $\left.{ }^{3} J 2.1 \mathrm{~Hz}, 6 \mathrm{H}, \mathrm{NMe}\right), 4.60$ (dd, $\left.{ }^{2} J 14.0,{ }^{3} J 4.6 \mathrm{~Hz}, 2 \mathrm{H}, 8-\mathrm{H}, 15-\mathrm{H}\right), 5.68\left(\mathrm{~d},{ }^{2} J 14.0 \mathrm{~Hz}, 2 \mathrm{H}\right.$, 8-H, 15-H), 7.70 (t, $\left.{ }^{3} J 8.1 \mathrm{~Hz}, 2 \mathrm{H}, 10-\mathrm{H}, 13-\mathrm{H}\right), 7.83-7.91$ (m, 4 H, 2-H, 5-H, 9-H, 14-H), 8.158.25 (m, 6 H, 1-H, 3-H, 4-H, 6-H, 11-H, 12-H), 19.55 (br s, $\left.1 \mathrm{H}, \mathrm{NHN}^{+}\right) .{ }^{1} \mathrm{H} \mathrm{NMR}\left(\mathrm{CD}_{3} \mathrm{CN}\right): \delta=$ $2.95\left(\mathrm{~d},{ }^{3} J 2.7 \mathrm{~Hz}, 6 \mathrm{H}, \mathrm{NMe}\right), 4.49$ (dd, $\left.{ }^{2} J 14.1,{ }^{3} J 4.9 \mathrm{~Hz}, 2 \mathrm{H}, 8-\mathrm{H}, 15-\mathrm{H}\right), 5.47\left(\mathrm{~d},{ }^{2} J 14.1 \mathrm{~Hz}\right.$, $2 \mathrm{H}, 8-\mathrm{H}, 15-\mathrm{H}), 7.68$ (t, $\left.{ }^{3} \mathrm{~J} 8.2 \mathrm{~Hz}, 2 \mathrm{H}, 10-\mathrm{H}, 13-\mathrm{H}\right), 7.79-7.88$ (m, 4 H, 2-H, 5-H, 9-H, 14-H), 8.03 (dd, ${ }^{3} J$ 7.7, ${ }^{4} J 0.9$ Hz, 2 H, 1-H, 6-H), 8.15 (dd, ${ }^{3} J$ 8.4, ${ }^{4} J 0.9$ Hz, 2 H, 3-H, 4-H), 8.20 (dd, ${ }^{3} J$ 8.2, ${ }^{4} J 1.5 \mathrm{~Hz}, 2 \mathrm{H}, 11-\mathrm{H}, 12-\mathrm{H}$ ), 19.95 (br s, $1 \mathrm{H}, \mathrm{NHN}^{+}$). $\mathrm{C}_{24} \mathrm{H}_{23} \mathrm{ClN}_{2} \mathrm{O}_{4}$ (438.91): calcd. C 65.68, H 5.28, N 6.38; found C 65.49, H 5.25, N 6.36\%.

2-(8-Dimethylaminonaphth-1-yl)-2,3-dihydro-1H-benz[de]isoquinoline (15). 1-Dimethylamino-8-methylaminonaphthalene ${ }^{10}(0.096 \mathrm{~g}, 0.47 \mathrm{mmol})$, 1,8-bis(bromomethyl)naphthalene 
$(0.150 \mathrm{~g}, 0.47 \mathrm{mmol})$ in a mixture of toluene $(3 \mathrm{~mL})$ and acetonitrile $(3 \mathrm{~mL})$ was refluxed for $3 \mathrm{~h}$. The product was isolated and purified as described for compound 9. Column chromatography gave 15 as light-brown solid $(0.085 \mathrm{~g}, 53 \%), \mathrm{mp} 86-87{ }^{\circ} \mathrm{C}(\mathrm{EtOAc}) .{ }^{1} \mathrm{H} \mathrm{NMR}\left(\mathrm{CDCl}_{3}\right): \delta=2.42$ (s, $6 \mathrm{H}, \mathrm{NMe}_{2}$ ), 4.48 (d, $\left.{ }^{2} J 14.5 \mathrm{~Hz}, 2 \mathrm{H}, 1-\mathrm{H}, 3-\mathrm{H}\right), 4.77$ (d, $\left.{ }^{2} J 14.5 \mathrm{~Hz}, 2 \mathrm{H}, 1-\mathrm{H}, 3-\mathrm{H}\right), 7.05$ (dd, ${ }^{3} J$ 7.4, $\left.{ }^{4} J 1.0 \mathrm{~Hz}, 1 \mathrm{H}, 7^{\prime}-\mathrm{H}\right), 7.24-7.31$ (m, $\left.3 \mathrm{H}, 4-\mathrm{H}, 9-\mathrm{H}, 2^{\prime}-\mathrm{H}\right), 7.40-7.60$ (m, $6 \mathrm{H}, 3$ '-H, 4'-H, 5'-H, 6'-H, 5-H, 8-H), 7.82 (d, $\left.{ }^{3} J 8.1 \mathrm{~Hz}, 2 \mathrm{H}, 6-\mathrm{H}, 7-\mathrm{H}\right) .{ }^{13} \mathrm{C} \mathrm{NMR}\left(\mathrm{CDCl}_{3}\right): \delta=45.0(\mathrm{~N}-\mathrm{Me})$, $56.9\left(\mathrm{~N}-\mathrm{CH}_{2}-\mathrm{Ar}\right), 113.9,114.4,121.6,121.9,122.3,123.5,125.5,125.6,125.7,125.9,128.4$, 133.3, 135.0, 138.0, 149.1, 150.8. MS, m/z (\%): $338[\mathrm{M}]^{+}$(80), 323 (5), 292 (22), 186 (56), 170 (100), 153 (94), 140 (64), 127 (46), 115 (76), 63 (53). $\mathrm{C}_{24} \mathrm{H}_{22} \mathrm{~N}_{2}$ (338.45): calcd. C 85.17, H 6.55, N 8.28; found C 85.28, H 6.34, N 8.19\%.

2-(8-Dimethylaminonaphth-1-yl)-2,3-dihydro-1H-benz $[\mathrm{de}]$ isoquinoline hydroperchlorate (15. HClO4): colorless crystals, mp 252-253 ${ }^{\circ} \mathrm{C}(\mathrm{MeCN}) .{ }^{1} \mathrm{H}$ NMR $\left(\mathrm{DMSO}-\mathrm{d}_{6}\right): \delta=2.74\left(\mathrm{~d},{ }^{3} \mathrm{~J}\right.$ $3.7 \mathrm{~Hz}, 6 \mathrm{H}, \mathrm{NMe}_{2}$ ), 4.99 (ABq, ${ }^{2} J 14.8 \mathrm{~Hz}, 4 \mathrm{H}, \mathrm{NCH}_{2} \mathrm{Ar}$ ), 7.43 (br d, ${ }^{3} J 7.1 \mathrm{~Hz}, 2 \mathrm{H}$ ), 7.61 (dd, ${ }^{3} J$ 8.1, $\left.{ }^{4} J 1.0 \mathrm{~Hz}, 2 \mathrm{H}\right), 7.74-7.87$ (m, $\left.2 \mathrm{H}\right), 7.99$ (br d, $\left.{ }^{3} J 8.1 \mathrm{~Hz}, 2 \mathrm{H}\right), 8.10-8.24$ (m, $\left.4 \mathrm{H}\right), 18.46$ (br s, $1 \mathrm{H}, \mathrm{NHN}^{+}$). $\mathrm{C}_{24} \mathrm{H}_{23} \mathrm{ClN}_{2} \mathrm{O}_{4}$ (438.91): calcd. C 65.68, H 5.28, N 6.38; found C 65.52, $\mathrm{H}$ $5.13, \mathrm{~N} 6.24 \%$.

1,8-Bis(2,3-dihydro-1H-benz[de]isoquinolin-2-yl)naphthalene (18). 1,8-Diaminonaphthalene $(0.038 \mathrm{~g}, 0.24 \mathrm{mmol}), 1,8$-bis(bromomethyl)naphthalene $(0.150 \mathrm{~g}, 0.48 \mathrm{mmol})$ and triethylamine $(0.14 \mathrm{~mL}, 0.96 \mathrm{mmol})$ in a mixture of toluene $(3 \mathrm{~mL})$ and acetonitrile $(3 \mathrm{~mL})$ was refluxed for 5 h. The product was isolated and purified as described for compound 9. Column chromatography gave $18(0.104 \mathrm{~g}, 94 \%)$ as grey crystals, mp $192-194{ }^{\circ} \mathrm{C}(\mathrm{MeCN}) .{ }^{1} \mathrm{H} \mathrm{NMR}\left(\mathrm{CDCl}_{3}\right): \delta=4.25$ (d, $\left.{ }^{2} J 14.9 \mathrm{~Hz}, 4 \mathrm{H}, 1^{\prime}-\mathrm{H}, 3^{\prime}-\mathrm{H}\right), 4.54$ (d, $\left.{ }^{2} J 14.9 \mathrm{~Hz}, 4 \mathrm{H}, 1^{\prime}-\mathrm{H}, 3{ }^{\prime}-\mathrm{H}\right), 6.90$ (br d, ${ }^{3} J 7.0 \mathrm{~Hz}, 4 \mathrm{H}$, 4'-H, 9'-H), 7.03 (t, ${ }^{3} J 8.2$ Hz, 4 H, 5'-H, 8'-H), 7.22 (br d, ${ }^{3} J$ 7.6 Hz, 2 H, 2-H, 7-H), 7.32-7.42 $\left(\mathrm{m}, 6 \mathrm{H}, 3-\mathrm{H}, 6-\mathrm{H}, 6 \mathrm{6}^{-\mathrm{H}}, 7 \mathrm{-}-\mathrm{H}\right), 7.52\left(\mathrm{dd},{ }^{3} J 8.2,{ }^{4} \mathrm{~J} 1.3 \mathrm{~Hz}, 2 \mathrm{H}, 4-\mathrm{H}, 5-\mathrm{H}\right) .{ }^{13} \mathrm{C} \mathrm{NMR}\left(\mathrm{CDCl}_{3}\right): \delta=$ $57.3\left(\mathrm{CH}_{2}\right), 115.4,121.5,122.3,124.2,125.5,126.1,126.2,127.9,132.8,134.1,138.4,149.6$. MS, $m / z(\%): 462[\mathrm{M}]^{+}$(18), 309 (100), 294 (17), 231 (10), 166 (22), 153 (38), 127 (14), 115 (24). $\mathrm{C}_{34} \mathrm{H}_{26} \mathrm{~N}_{2}$ (462.60): calcd. C 88.28, H 5.67, N 6.05; found C 88.51, H 5.34, N 6.15\%. 1,8Bis(2,3-dihydro-1H-benz[de]isoquinolin-2-yl)naphthalene hydroperchlorate $\left(\mathbf{1 8} \cdot \mathbf{H C l O}_{4}\right)$ : beige crystals, mp $252-253{ }^{\circ} \mathrm{C}(\mathrm{MeCN}) .{ }^{1} \mathrm{H}$ NMR $\left(\mathrm{DMSO}-\mathrm{d}_{6}\right): \delta=4.83-5.04\left(\mathrm{~m}, 8 \mathrm{H}, 1^{\prime}-\mathrm{H}, 3^{\prime}-\right.$ H), 6.86 (br d, $\left.{ }^{3} J 6.8 \mathrm{~Hz}, 4 \mathrm{H}, 4^{\prime}-\mathrm{H}, 9^{\prime}-\mathrm{H}\right), 7.13$ (t, $\left.{ }^{3} J 7.7 \mathrm{~Hz}, 4 \mathrm{H}, 5^{\prime}-\mathrm{H}, 8^{\prime}-\mathrm{H}\right), 7.46$ (br d, ${ }^{3} J 8.1$ Hz, 4 H, 6'-H, 7'-H), 7.95 (t, ${ }^{3} J 7.9$ Hz, 2 H, 3-H, 6-H), 8.26 (br d, ${ }^{3} J 7.5$ Hz, 2 H, 2-H, 7-H), 8.36 (br d, ${ }^{3} J 8.4 \mathrm{~Hz}, 2 \mathrm{H}, 4-\mathrm{H}, 5-\mathrm{H}$ ), 19.33 (br s, $1 \mathrm{H}, \mathrm{NHN}^{+}$). $\mathrm{C}_{34} \mathrm{H}_{27} \mathrm{ClN}_{2} \mathrm{O}_{4}$ (563.05): calcd. C 72.53, H 4.83, N 4.98; found C 72.59, H 4.62, N 4.62\%.

Reaction of 2,2-dimethyl-2,3-dihydroperimidine with 1,8-bis(bromomethyl)naphthalene. 2,2-Dimethyl-2,3-dihydroperimidine ${ }^{11}(0.094 \mathrm{~g}, 0.48 \mathrm{mmol}), 1,8$-bis(bromomethyl)naphthalene $(0.150 \mathrm{~g}, 0.48 \mathrm{mmol})$ and triethylamine $(0.06 \mathrm{~mL}, 0.48 \mathrm{mmol})$ in a mixture of toluene $(3 \mathrm{~mL})$ and acetonitrile $(3 \mathrm{~mL})$ was refluxed for $5 \mathrm{~h}$. The reaction mixture was poured into ice-water $(30$ $\mathrm{mL}$ ) and basified with potassium hydroxide to $\mathrm{pH} 10-11$, and the products were extracted with dichloromethane $(3 \times 15 \mathrm{~mL})$. The organic phase was dried over $\mathrm{Na}_{2} \mathrm{SO}_{4}$, evaporated to dryness 
and subjected to column chromatography (silica gel, $\mathrm{CH}_{2} \mathrm{Cl}_{2}$ ) to afford the following products in order of elution:

7-Isopropyl-7,7a,14,15-tetrahydrobenz[4,5,6]isoquinolino[2,1-a]perimidine (27). Yield 27\%; beige crystals with mp $205-207{ }^{\circ} \mathrm{C}\left(\mathrm{CH}_{2} \mathrm{Cl}_{2}\right) .{ }^{1} \mathrm{H} \mathrm{NMR}\left(\mathrm{CDCl}_{3}\right): \delta=1.39\left(\mathrm{~d},{ }^{3} \mathrm{~J} 6.5 \mathrm{~Hz}, 3 \mathrm{H}\right.$, $\left.\mathrm{CH}_{3}\right), 1.51\left(\mathrm{~d},{ }^{3} J 6.8 \mathrm{~Hz}, 3 \mathrm{H}, \mathrm{CH}_{3}\right), 4.38-4.53(\mathrm{~m}, 1 \mathrm{H}, \mathrm{CHMe}), 5.02\left(\mathrm{~d},{ }^{2} J 16.9 \mathrm{~Hz}, 1 \mathrm{H}\right.$, $\left.\mathrm{NCH}_{2} \mathrm{Ar}\right), 5.30$ (d, $\left.{ }^{2} J 16.9 \mathrm{~Hz}, 1 \mathrm{H}, \mathrm{NCH}_{2} \mathrm{Ar}\right), 6.03$ (s, $\left.1 \mathrm{H}, \mathrm{NCHN}\right), 6.64\left(\mathrm{dd},{ }^{3} J\right.$ 6.8, ${ }^{4} \mathrm{~J} 1.7 \mathrm{~Hz}, 1$ $\mathrm{H}), 6.96-7.06(\mathrm{~m}, 3 \mathrm{H}), 7.11\left(\mathrm{dd},{ }^{3} J\right.$ 8.0, $\left.{ }^{4} \mathrm{~J} 0.8 \mathrm{~Hz}, 1 \mathrm{H}\right), 7.17-7.23(\mathrm{~m}, 1 \mathrm{H}), 7.28-7.40(\mathrm{~m}, 3 \mathrm{H})$, 7.46-7.55 (m, $2 \mathrm{H}), 7.57-7.63(\mathrm{~m}, 1 \mathrm{H}) .{ }^{13} \mathrm{C} \mathrm{NMR}\left(\mathrm{CDCl}_{3}\right): \delta=21.9\left(\mathrm{CH}_{3}\right), 22.3\left(\mathrm{CH}_{3}\right), 51.3$ $\left(\mathrm{CCH}_{3}\right), 55.4\left(\mathrm{NCH}_{2}\right), 69.2(\mathrm{NCHN}), 106.2,111.6,117.7,118.3,119.2,123.5,123.8,125.8$, $126.2,126.7,127.0,127.2,127.5,129.6,131.5,133.9,135.0,135.9,141.9,142.3 . \mathrm{MS}, \mathrm{m} / \mathrm{z}$ (I(\%)): $350[\mathrm{M}]^{+}$(29), 307 (28), 292 (11), 183 (34), 168 (25), 152 (40), 139 (26), 127 (27), 115 (12), 43 (100). $\mathrm{C}_{25} \mathrm{H}_{22} \mathrm{~N}_{2}$ (350.47): calcd. C 85.68, H 6.33, N 7.99; found C 85.32, H 6.47, N $8.06 \%$.

2-(8-Aminonaphth-1-yl)-2,3-dihydro-1H-benz[de]isoquinoline (28). Yield 6\%; beige crystals with mp 90-91 ${ }^{\circ} \mathrm{C}\left(\mathrm{CH}_{2} \mathrm{Cl}_{2}\right) .{ }^{1} \mathrm{H}$ NMR $\left(\mathrm{CDCl}_{3}\right): \delta=4.50\left(\mathrm{ABq},{ }^{2} J 14.9 \mathrm{~Hz}, 4 \mathrm{H}, \mathrm{NCH}_{2}\right), 5.84$ (br s, $2 \mathrm{H}, \mathrm{NH}_{2}$ ), $6.52\left(\mathrm{dd},{ }^{3} J 5.7,{ }^{4} J 1.6 \mathrm{~Hz}, 1 \mathrm{H}, 7^{\prime}-\mathrm{H}\right), 7.13-7.23$ (m, $\left.2 \mathrm{H}, 2^{\prime}-\mathrm{H}, 66^{\prime}-\mathrm{H}\right), 7.25-7.48$ (m, 6 H, 4-H, 9-H, 5'-H, 3'-H, 5-H, 8-H), 7.57 (dd, $\left.{ }^{3} J 6.6,{ }^{4} J 1.3 \mathrm{~Hz}, 1 \mathrm{H}, 4^{\prime}-\mathrm{H}\right), 7.77$ (br d, ${ }^{3} J 8.2$ $\mathrm{Hz}, 2 \mathrm{H}, 6-\mathrm{H}, 7-\mathrm{H}) .{ }^{13} \mathrm{C} \mathrm{NMR}\left(\mathrm{CDCl}_{3}\right): \delta=58.1\left(\mathrm{CH}_{2}\right), 110.6,116.2,117.7,120.4,122.5,125.8$, 126.2, 126.5, 126.9, 127.2, 127.9, 133.7, 134.0, 137.6, 145.6, 150.3. IR $\left(\mathrm{CCl}_{4}, v / \mathrm{cm}^{-1}\right): 3474$, $3318\left(\mathrm{NH}_{2}\right), 3058,2959,2928,2867,2857,2788(\mathrm{CH}), 1586$ (Ar). $\mathrm{C}_{22} \mathrm{H}_{18} \mathrm{~N}_{2}$ (310.40): calcd. C 85.13, H 5.84, N 9.03; found C 85.27, H 5.47, N 9.11\%.

1,8-Bis(2,3-dihydro-1H-benz[de]isoquinolin-2-yl)naphthalene (18). Yield 18\%; the properties are the same as described above for the compound prepared from 1,8-diaminonaphthalene.

\section{Acknowledgements}

We thank Z. A. Starikova (A. N. Nesmeyanov Institute of Organoelement Compounds of the Russian Academy of Sciences, Moscow) for performing the X-ray diffraction experiment. This work was supported by the Russian Foundation for Basic Research (grant RFBR 11-03-00073).

\section{References}

1. Hibbert, F. Acc. Chem. Res. 1984, 17, 115-120. http://dx.doi.org/10.1021/ar00099a006

2. Pozharskii, A. F.; Ozeryanskii, V. A. Proton sponges, in The Chemistry of Anilines; Rappoport, Z., Ed.; J. Wiley \& Sons: Chichester, 2007; Part 2, Ch. 17, pp. 931-1026. 
3. Pozharskii, A. F.; Ozeryanskii, V. A.; Filatova, E. A. Chem. Heterocycl. Compd. 2012, 48, 200-219. http://dx.doi.org/10.1007/s10593-012-0983-5

4. Kanbara, T.; Suzuki, Y.; Yamamoto, T. Eur. J. Org. Chem. 2006, 3314-3316. http://dx.doi.org/10.1002/ejoc.200600411

5. Brzezinski, B.; Glowiak, T.; Grech, E.; Malarski, Z.; Sobczyk, L. J. Chem. Soc., Perkin Trans. 2 1991, 1643-1647. http://dx.doi.org/10.1039/p29910001643

6. Vinogradova, O. V.; Pozharskii, A. F.; Starikova, Z. A. Russ. Chem. Bull. 2003, 52, 208217. http://dx.doi.org/10.1023/A:1022477205623

7. Mazaleyrat, J. P.; Wright, K. Tetrahedron Lett. 2008, 49, 4537-4541. http://dx.doi.org/10.1016/j.tetlet.2008.05.042

8. Day, V. W.; Hossain, M. A.; Kang, S. O.; Powell, D.; Lushington, G.; Bowman-James, K. J. Am. Chem. Soc. 2007, 129, 8692-8693.

http://dx.doi.org/10.1021/ja0724745

PMid:17585768

9. Benoit, R. L.; Lefebvre, D.; Frechette, M. Can. J. Chem. 1987, 65, 996-1001. http://dx.doi.org/10.1139/v87-170

10. Ozeryanskii, V. A.; Pozharskii, A. F.; Koroleva, M. G.; Shevchuk, D. A.; Kazheva, O. N.; Chekhlov, A. N.; Shilov, G. V.; Dyachenko, O. A. Tetrahedron 2005, 61, 4221-4232. http://dx.doi.org/10.1016/j.tet.2005.02.067

11. Ozeryanskii, V. A.; Filatova, E. A.; Sorokin, V. I.; Pozharskii, A. F. Russ. Chem. Bull. 2001, $50,846-853$.

http://dx.doi.org/10.1023/A:1011359109826

12. Alder, R. W.; Bryce, M. R.; Goode, N. C.; Miller, N.; Owen, J. J. Chem. Soc., Perkin Trans. 1 1981, 2840-2847.

13. Charmant, J. P. H.; Lloyd-Jones, G. C.; Peakman, T. M.; Woodward, R. L. Eur. J. Org. Chem. 1999, 2501-2510. http://dx.doi.org/10.1002/(SICI)1099-0690(199910)1999:10<2501::AIDEJOC2501>3.0.CO;2-5

14. Hodgson, P.; Lloyd-Jones, G. C.; Murray, M.; Peakman, T. M.; Woodward, R. L. Chem.Eur. J. 2000, 6, 4451-4460. http://dx.doi.org/10.1002/1521-3765(20001215)6:24<4451::AID-CHEM4451>3.0.CO;2-H

15. Mitchell, R. H.; Sondheimer, F. Tetrahedron 1968, 24, 1397-1405. http://dx.doi.org/10.1016/0040-4020(68)88091-3 


\section{Graphical Abstract}

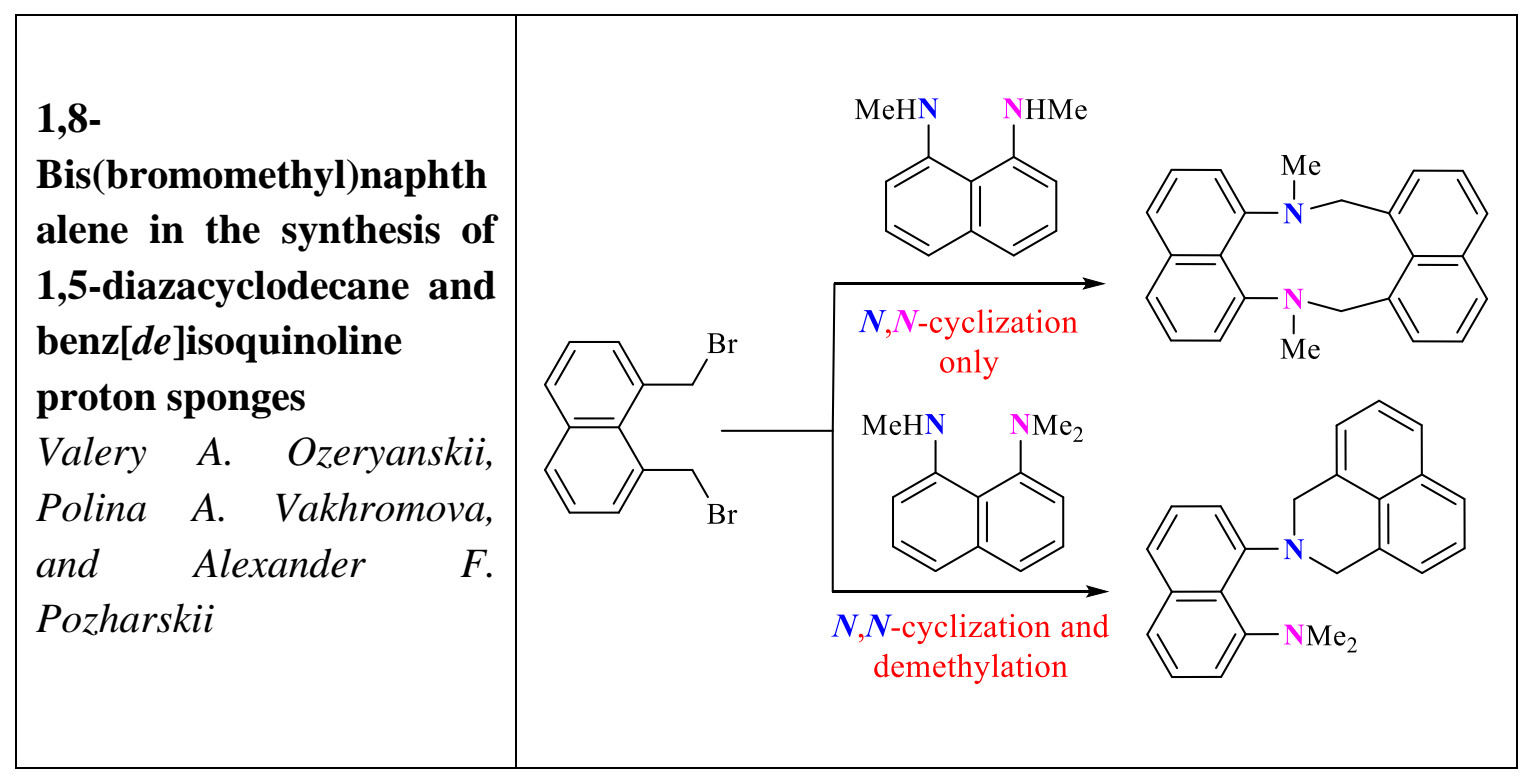

